<原 著 $>$

硬変合併小肝癌に対する腫瘤核出術の予後の検討

\begin{tabular}{|c|c|c|c|c|}
\hline 高崎 & 健 & 小林誠一郎 & 武藤 & 晴臣 \\
\hline 済陽 & 高穂 & 斉藤 明子 & 秋本 & 伸 \\
\hline 礒辺 & 義憲 & 上田 哲也 & 田中 & 精一* \\
\hline
\end{tabular}

要 旨：肝硬变合併の小さな肝癌に対する縮小手術としての腫瘤核出術の手術成績について検 討を行なった。 26例の対象症例の $5 ち 3$ 年以上生存例は 7 例であり，内 5 例は現在生存中であ る. 最長生存 4 年 6 カ月であり, 累積生存率は 4 年で $52 \%$ ガ得られている. 術後再発例は 9 例 あるが，この内切断端よりの再発は 3 例であり，残る 6 例は初回とは異なる区域への再発であ る.この切除断端再発 3 例の切除標本の病理組織検索では, 被膜形成が不完全であったもの打 よび被膜外浸潤が認められている例であり，この部位近くで癌遺残が起っていたものと思われ る.これら 3 例の反省に立脚し，より根治性を向上させるには適応をより敩格にせねばならず， このため現時点では, 術中超音波検查の判断を重視し，原則として腫瘤の長径が $3 \mathrm{~cm}$ 以下の小 さな肝癌で，全周性に明瞭な被膜がありと判断され，しかも被膜外浸潤および娘結節のないと された例に限って適応とせねばならない。

卖引用語：硬変合併小肝癌腫瘤核出術原発性肝癌

\section{粕 言}

肝癌に対する肝切除に際しても，通常の癌手術と同 様に根治性を増すためには周囲に大きな非癌組織を含 めた拡大手術が望をれる。しかしわが国の肝癌の70\% 以上は肝硬変を合併しているために，そのような大き な肝組織の切除は肝機能面での制約を受けることとな り, 根治性とともに肝硬变症としての予後を考え合せ た上で縮小した術式の選択がなされなければならな い.

近年超音波検査法の発展に伴い, 肝硬变症の経過追 求中に小さな肝癌が発見される機会は増してきてい る.このような硬変合併肝癌に対しわれわれは可及的 に肝機能を温存することを目的として最も縮小した手 術として腫瘤核出術”を行ってきた。 そこで今回，この ような形の縮小手術の根治性の問題について，予後調 查を加え検討した。

\section{腫瘤核出術術式と適応}

高度の硬変肝の中に発生した小さな肝癌が対象とな るが，その多くは術中肉眼的には存在部位が不明瞭で あるため超音波がイド下に手術が行われる。

* 東京女子医科大学消化器病センター 〈受付日59年10月17日>
原則的に腫湯の長径が $3 \mathrm{~cm}$ 以下の例で，術中超音波 検査で明瞭な被膜が不整なく全周性に認められ，被膜 外浸潤，娘結節がないと思われる症例が対象となる。 手術に当っては, 超音波ガイド下で腫瘤に最短距離と 思われる肝表面に核出範囲をマークする。この時肝静 脈枝および内脈枝の走行が確認できる例では腫瘤なら びに切断面との位置関係を記憶しておく．肝表面の マークに沿って通常のティースプーンを用いて肝内に 切り込んでゆくが，この時スプーンの腹側に腫瘤を抱 き込む形で圧排しておくことにより，切断面に出てく る血管を結紮してゆくことができる。通常 $1 \mathrm{~cm}$ 程度の 非癌組織を全周性につけた形の切除を目指している (Fig. 1, 2, 3).

\section{検討対象症例}

われわれの原発性肝癌に対する肝切除術症例は 125 例であり，内97例， $77.6 \%$ が肝硬变合併例である (Table 1).これら肝硬変例中の31例に対し睡瘤核出 術を行っているが内 5 例は多発癌で, 切除し得なかっ た小病巣が残ってしまったものであるため除き，26例 を検討対象とした(Table 2). 症例の内訳は男性25例, 女性 1 例，年齢は28 74歳，平均約56歳である，最大 径でみた腫瘍の大きさは， $1.1 \mathrm{~cm} \sim 4.5 \mathrm{~cm}$ であり平均 $2.55 \pm 0.9 \mathrm{~cm}$ である.肝機能を ICG 15分停滞率でみる 


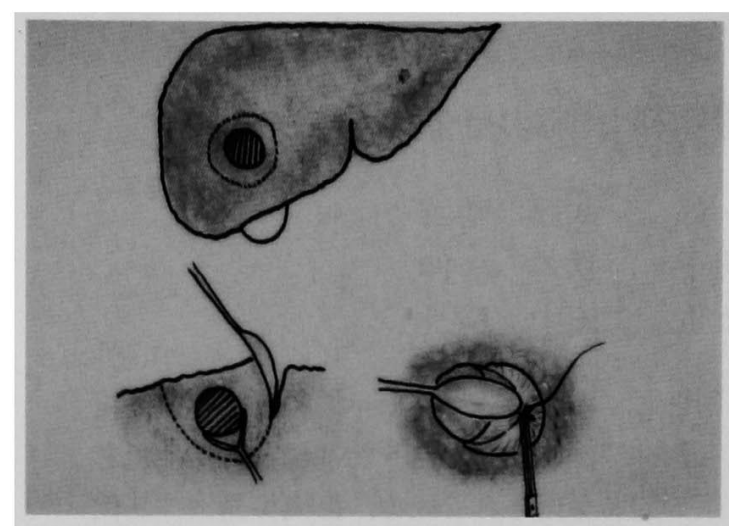

Fig. 1 Procedure of enucleation method.

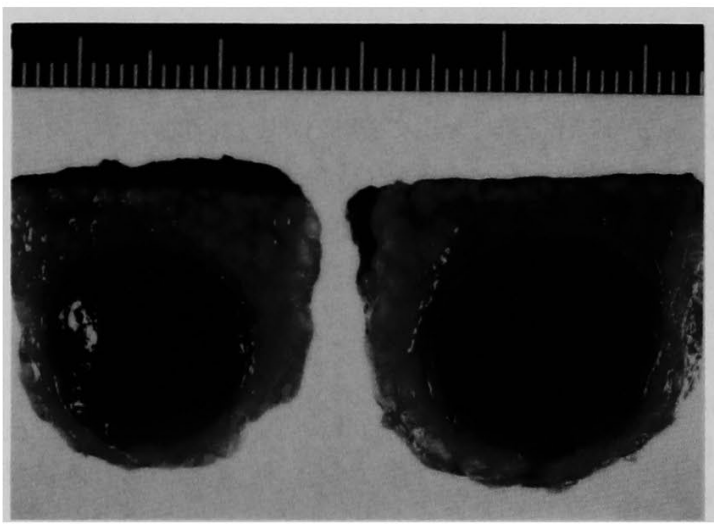

Fig. 2 Resected specimen after enucleation.

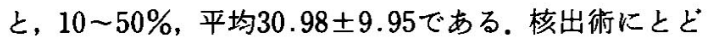
めた理由についてみると，高齢者であるためといら理 由が 2 例，食道静脈瘤に対する手術を同時に行ったた めが 8 例, 肝機能不良のためか 5 例, 更に肝不全症状 を伴っているためか～ 4 例，多発例で 2 力所以上の病巣 切除を行わねばならなかったためが 6 例，その他胃癌 合併が 1 例である。

同しくわれわれの症例中，区域切除，あるいは亜区

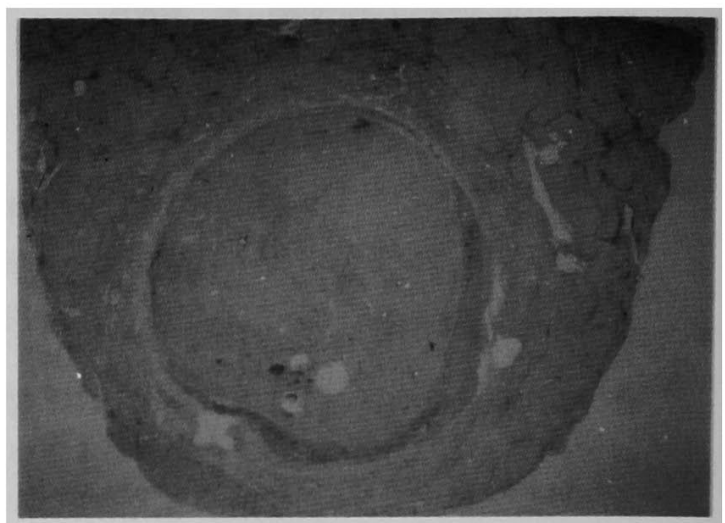

Fig. 3 By microscopic film, We can see that, there are about $5 \mathrm{~mm}$ wide of non cancerous liver all around the encapsulated small liver cancer.

域切除症例中で主病巣が4cm 以内の症例16例につい て切除標本の組織所見と超音波検査所見について対比 検討を加えた。

\section{成績と結果 \\ 1）核出術症例の予後}

26例の予後をみる上現在生存中の症例は15例であ り。最長生存例は 4 例 6 力月である。肝不全死は 9 例, 癌死 2 例である。これら全症例中で肝に癌再発の認め られた症例は 9 例あり(Fig. 4の々印)，生存中のもの 6 例, 肝不全死 2 例, 癌死 1 例である.

再発が認めら九た生存例に対し再発発見時, 再切除 1 例, 肝動脈栓塞術 3 例に行っている. 累積生存率は

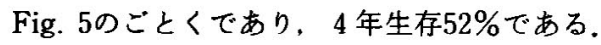

肝不全死例の中の 2 再発例はいずれも小病巣であ ク，1例は剖検ではじめて発見されたもので，いずれ もこれが肝不全の直接原因とは考えられないるのであ る.

肝への再発による癌死の 1 例は 1 年 4 力月後に再切 除を行った症例であるが, 術後再び多発性の再発が急

Table 1 Hepatic Resection for HCC.

\begin{tabular}{c|c|c|c|c|c|l}
\hline & $\begin{array}{c}\text { Extended } \\
\text { lobectomy }\end{array}$ & Lobectomy & $\begin{array}{c}\text { Segment- } \\
\text { Subsegmental } \\
\text { resection }\end{array}$ & $\begin{array}{c}\text { Parcial } \\
\text { resection }\end{array}$ & Enucleation & Total \\
\hline $\begin{array}{c}\text { combined with } \\
\text { liver cirrhosis }\end{array}$ & $6(4)$ & $11(3)$ & $41(1)$ & 8 & 31 & 97 \\
\hline not cirrhosis & $8(1)$ & $12(1)$ & $8(2)$ & & & 28 \\
\hline & $14(5)$ & $23(4)$ & $49(3)$ & 8 & 31 & $125(12)$ \\
\hline
\end{tabular}


Table 2 Cases of Enucleation for HCC.

$(\mathrm{N}=26)$

\begin{tabular}{|c|c|c|c|c|}
\hline Case & Sex & Age & ICG $R_{15}$ & Reason for enucleation \\
\hline $1 \mathrm{Y} . \mathrm{T}$. & $\mathbf{M}$ & 74 & $35 \%$ & Aged \\
\hline 2 T.N. & $\mathbf{M}$ & 63 & 39 & Varices \\
\hline $3 \mathrm{M} . \mathrm{T}$. & $\mathbf{M}$ & 38 & 25 & Varices \\
\hline $4 \mathrm{~T} \cdot \mathrm{U}$ & M & 64 & 41 & Poor liver function \\
\hline 5 T.M. & $\mathbf{M}$ & 68 & 15 & multiple tumor \\
\hline $6 \mathrm{H.O}$. & $\mathbf{M}$ & 69 & 27 & Aged \\
\hline $7 \mathrm{M} . \mathrm{I}$ & $\mathbf{F}$ & 60 & 10 & multiple tumor \\
\hline $8 \mathrm{~T} . \mathrm{N}$. & $\mathbf{M}$ & 47 & 32 & Liver insufficiency \\
\hline 9 S.E. & $\mathbf{M}$ & 54 & 43 & Poor liver function \\
\hline $10 \mathrm{~J} . \mathrm{F}$. & M & 47 & 17 & multiple tumor \\
\hline 11 I.U. & M & 53 & 24 & Varices \\
\hline $12 \mathrm{H} . \mathrm{H}$. & $\mathbf{M}$ & 45 & 31 & Varices \\
\hline $13 \mathrm{~K} . \mathrm{I}$. & $\mathbf{M}$ & 68 & 30 & Varices \\
\hline $14 \mathrm{~K} . \mathrm{Y}$ & $\mathbf{M}$ & 53 & 12 & Gastric cancer \\
\hline 15 N.T. & M & 66 & 30 & Varices \\
\hline $16 \mathrm{H.H}$. & $\mathbf{M}$ & 28 & 28 & Varices \\
\hline $17 \mathrm{~K} \cdot \mathrm{W}$ & $\mathbf{M}$ & 51 & 35 & Poor liver function \\
\hline 18 H.M. & M & 68 & 40 & Liver insufficiency \\
\hline 19 S.T. & $\mathbf{M}$ & 47 & 25 & Liver insufficiency \\
\hline $20 \mathrm{~T} . \mathrm{K}$. & $\mathbf{M}$ & 56 & 50 & Poor liver function \\
\hline 21 E.M. & $\mathbf{M}$ & 65 & 37 & Liver insufficiency \\
\hline 22 Y.A. & $\mathbf{M}$ & 45 & 29 & Varices \\
\hline $23 \mathrm{~S} . \mathrm{T}$. & $\mathbf{M}$ & 72 & 24 & multiple tumor \\
\hline 24 K.S. & M & 58 & 45 & multiple tumor \\
\hline 25 T.T. & $\mathbf{M}$ & 48 & 28 & multiple tumor \\
\hline 26 N.Y. & $\mathbf{M}$ & 53 & 35 & Poor liver function \\
\hline
\end{tabular}

速に発育し癌死となった。

\section{2) 再発例の検討}

再発例での再発部位について検討してみると，初回 手術と同じ垔区域内での再発が 3 例, 異なる亜区域内 への再発が 6 例である (Fig. 6,7). 同じ垔区域内の再 発を断端再発としたがこれらの再発が診断されるまで の期間をみると， 2 年， 1 年10力月， 1 年 1 カ月とい ずれす 1 年以上経過後に発見されている。この 3 例の 病状释過を要䄪すると,

S.T. 例は径 $4 \mathrm{~cm}$ と比較的大きな畽湟であったが, 腹 水，軽度黄疸を伴らため，やむなく核出術とした例で ある. 術前画像診断で腫湯の境界の不明瞭な部分が
あったが，切除標本でやはり部分的に被膜外浸潤が認 められた例であり，この部に癌遭残が起ってしまった あのと思われる.

T.M. 例は初回 2 カ所を核出したものであるが，そ のうち $\mathrm{S}_{\mathbf{8}}$ の部に再発が認められた. 本例では非癌部の 肝硬変は高度ではなく, 切除標本では被膜は薄く，し かも全周性ではなく，この被膜の不明瞭な部での癌遗 残が疑われる。

H.O. 例は胆のう床に接した前区域下面に, 術前検査 で超音波検査のみで小結節が認められたが断定的に訮 癌とは診断され得なかった例で, AFP 值は3ng $/ \mathrm{m} l$ で あり，質的診断がつけられなかった，手術に際しては 術中超音波下に核出術を予定したが，術前超音波像に 比較し, 術中超音波像の方がむしろ不明瞭な像しか得 られず，結局は中ば盲目的な手術となってしまった。 切除標本の組織診断です確定診断がつかず，境界病変 とい5見方が強かったが， 1 年 1 カ月に同部に再発が 認められ，その時点ではじめて肝癌の確診となった症 例である。

初回手術とは異なる他の部位への再発の 6 例につい ては,これを多中心性発癌と考えるか, 肝内転移があっ たものと考えるべきであるかについては結論の出せな い問題であるが，再発が診断されるまでの期間は 2 年 8 力, 1 年10力月が 2 例あり, 断端再発よりはいく 分遅れる感がある。

\section{3）垔区域，区域切除例の検討}

主病巣が $4 \mathrm{~cm}$ 以下で，核出術る行い得るかと思われ た症例16例を検討対象とした，症例の内訳はTable 3 のごとくであり，切除標本において被膜の形成が認め られない例または不完全な例が 3 例あるが，これらは 術前画像診断に拈いて診断されている. 残る13例は被 膜を有しているが内 8 例で被膜外への浸潤が認められ ている.この内 4 例は娘結節を有しているすのである. 残る 4 例では被膜に接しての浸閏のみであり，これは 被膜の辺縁より周囲 $5 \mathrm{~mm}$ 以内の範囲にとどまってい る.

肉眼的に娘結節が標本で認められたものは6 例であ るが,これらはいずれも術前，術中超音波検查にて指 摘されており，それが理由で核出術の適応とはならな かったという要素もあった症例である，2 例で顕做鏡 的に発見された娘結節があった。

以上のよ5に被膜の無いもの，あるいは娘結節のあ るものは術中超音波検查にてそのほとんどが診断され ている。 


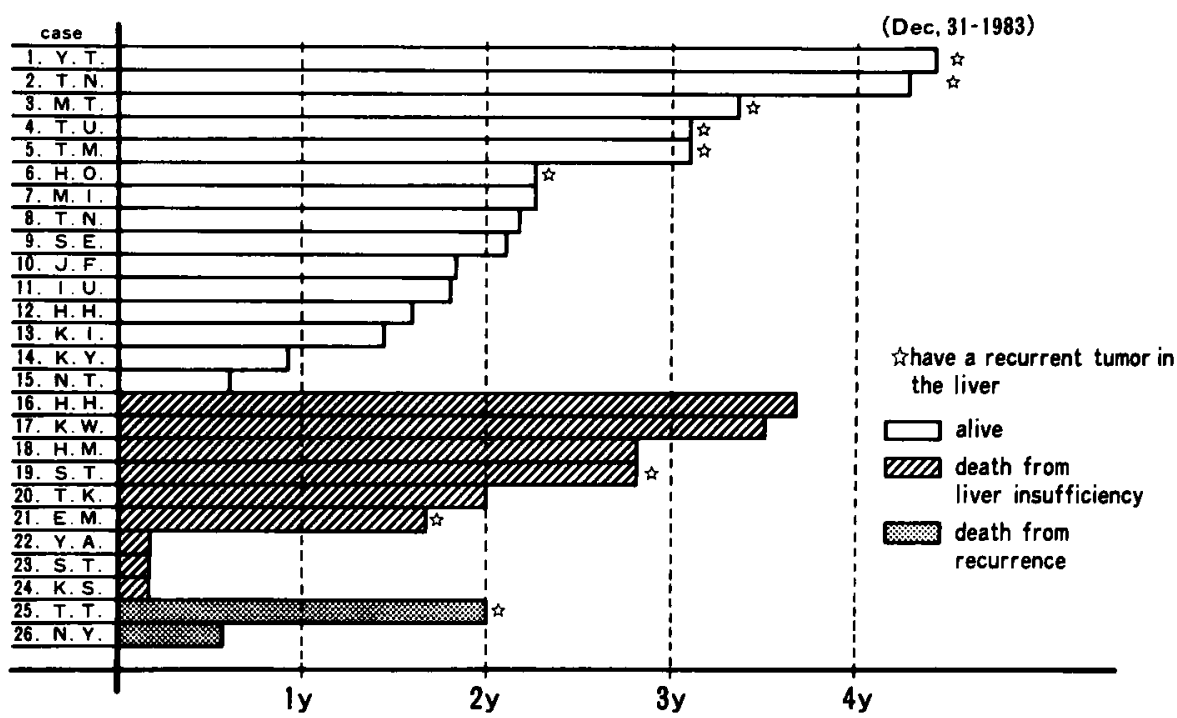

Fig. 4 Prognosis after Enucleation for Small HCC. (26 cases, combined with liver cirrhosis)

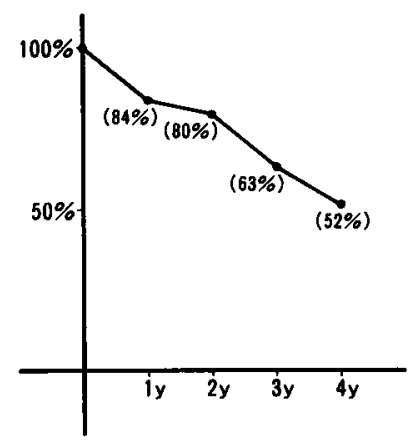

Fig. 5 Cumulative Survival rate after Enucleation for HCC. $(n=26)$

\section{考案}

肝硬変合併の小肝癌に対してどこまで手術の縮小化 を図ることが可能であるかといら点に関する検討のた め, 最す縮小した形の手術である腫瘤核出術の予後に ついての検討を行った。

たとえ小肝癌であってる腫湯部の門脈腫湯栓が77\% に認められるために経内脈的な肝内転移が容易に起っ ていると考えておかねばならないとの考えより，門脈 系についての系統的な切除が行われなければならない との山㥓2)らの主張はもっともなことであるがしかし ながら, 肝硬変といら制約のためにそのような切除が

\begin{tabular}{|c|c|c|c|c|c|c|}
\hline case & $\begin{array}{l}\text { Location and size } \\
\text { of tumor }\end{array}$ & $\begin{array}{l}\text { type of } \\
\text { L.C. }\end{array}$ & $\begin{array}{c}\text { Condition of } \\
\text { Capsule }\end{array}$ & HB virus & $\begin{array}{l}\text { Duration } \\
\text { after operation }\end{array}$ & $\begin{array}{l}\text { Location of } \\
\text { Recurrent tumor }\end{array}$ \\
\hline S. T. & & A & $\begin{array}{l}\text { Extra capsulare } \\
\text { invation }\end{array}$ & $\begin{array}{r}\mathrm{HBsAg}(+) \\
\mathrm{eAb}(-)\end{array}$ & $2 Y$ & \\
\hline T. M. & & $\mathbf{B}^{\prime}$ & $\begin{array}{l}\text { no circular } \\
\text { capsule }\end{array}$ & $\begin{array}{c}\mathrm{HBsAg}(+) \\
\mathrm{eAb}(-)\end{array}$ & IYIOMo & \\
\hline H. 0 . & & $\mathbf{B}^{\prime}$ & $\begin{array}{l}\text { no cicular } \\
\text { capsule }\end{array}$ & HBsAb(+) & IY 1 Mo & \\
\hline
\end{tabular}

Fig. 6 Recurrent cases after Enucleation, (1) (Recurrence on same subsegment). 


\begin{tabular}{|c|c|c|c|c|c|c|}
\hline case & $\begin{array}{l}\text { Location and size } \\
\text { of tumor }\end{array}$ & $\begin{array}{l}\text { type of } \\
\text { L.C. }\end{array}$ & $\begin{array}{l}\text { Condition of } \\
\text { Capsule }\end{array}$ & HB virus & $\begin{array}{l}\text { Duration } \\
\text { after operation }\end{array}$ & $\begin{array}{l}\text { Location of } \\
\text { Recurrent tumor }\end{array}$ \\
\hline Y.T. & & $\mathbf{B}$ & $\begin{array}{l}\text { Extra capsulare } \\
\text { invation } \\
(2 \text { m.内内 })\end{array}$ & $\begin{array}{r}\mathrm{HB} \text { HAg }(-) \\
\operatorname{sAb}(-)\end{array}$ & 9 Mo & \\
\hline T. N. & & A & $\begin{array}{l}\text { intra capsulare } \\
\text { invation }\end{array}$ & $\begin{array}{r}\operatorname{HBsAg}(-) \\
\operatorname{sAb}(-)\end{array}$ & $2 Y 8 \mathrm{Mo}$ & \\
\hline T. T. & & B & $\begin{array}{l}\text { intra capsulare } \\
\text { invation }\end{array}$ & $\begin{array}{r}\mathrm{HBsAg}(-) \\
\operatorname{sAb}(-)\end{array}$ & IY 4 Mo & \\
\hline E.M. & & A & Encapsulated & $\begin{array}{r}\text { HBsAg }(-) \\
\operatorname{sAb}(+)\end{array}$ & $8 \mathrm{Mo}$ & \\
\hline T.U. & & $\mathbf{B}$ & $\begin{array}{l}\text { intra capsulare } \\
\text { invation }\end{array}$ & $\begin{array}{r}\text { HBsAg(-) } \\
\text { sAb }(+)\end{array}$ & IYIOMo & \\
\hline M. T. & & B & $\begin{array}{l}\text { intra capsulare } \\
\text { invation }\end{array}$ & $\begin{array}{r}\text { HBsAg(t) } \\
\text { sAb(t) }\end{array}$ & IYIOMo & \\
\hline
\end{tabular}

Fig. 7 Recurrent cases after Enucleation, (II) (Recurrence on another subsegment).

Table 3 Condition of capsule.

Resection of Segment or Subsegment cases for $\mathrm{HCC} \phi(4 \mathrm{~cm}>)$

\begin{tabular}{|c|c|c|c|c|c|c|c|c|}
\hline case & & $\begin{array}{l}\text { cation } \\
\text { size }\end{array}$ & capsule & $\begin{array}{c}\text { intra capsule } \\
\text { invasion }\end{array}$ & & $\begin{array}{l}\text { capsule } \\
\text { asion }\end{array}$ & Daughter & $\begin{array}{l}\text { type of } \\
\text { L.C. }\end{array}$ \\
\hline T.O. & $\mathrm{S}_{6}$ & $1.5 \times 1.3$ & + & + & + & $2 \mathrm{~mm}>$ & - & B \\
\hline I. H. & $S_{4}$ & $2.5 \times 2.5$ & + & - & & - & - & B \\
\hline S.o. & $\mathrm{S}_{6}$ & $3.0 \times 3.5$ & + & + & + & $5 \mathrm{~mm}>$ & - & $\mathrm{B}^{\prime}$ \\
\hline T. T. & $S_{s}$ & $2.2 \times 2.8$ & - & I & & I & - & B \\
\hline S.Y. & $S_{5-8}$ & $2.4 \times 3.0$ & + & + & & + & $+{ }^{*}$ & $\mathrm{~B}^{\prime}$ \\
\hline M. K. & $S_{5-8}$ & $1.0 \times 1.2$ & - & 1 & & 1 & - & Fib \\
\hline Y.A. & $S_{4}$ & $3.2 \times 3.5$ & + & + & & + & $+{ }^{*}$ & B \\
\hline Y.S. & $S_{5}$ & $3.6 \times 3.0$ & + & + & & - & - & B \\
\hline K.Y. & $\mathrm{S}_{6}$ & $1.8 \times 2.4$ & + & - & & + & $+{ }^{\circ}$ & B \\
\hline K. T. & $S_{8}$ & $1.3 \times 1.5$ & + & - & & - & - & $\mathrm{B}^{\prime}$ \\
\hline M.N. & $S_{\mathbf{s}}$ & $1.7 \times 2.2$ & + & - & & - & $+*$ & Fib \\
\hline T.W. & $S_{s}$ & $1.5 \times 2.2$ & + & - & & - & + & A \\
\hline K. H. & $\mathrm{S}_{3}$ & $1.5 \times 1.6$ & + & + & & + & $+*$ & B \\
\hline F. I. & $\mathrm{S}_{4}$ & $3.2 \times 4.5$ & + & + & + & $5 \mathrm{~mm}>$ & - & A \\
\hline I.S. & $S_{5}$ & $1.6 \times 1.8$ & - & 1 & & I & + (micro) & B \\
\hline I. 0 . & $S_{3}$ & $3.1 \times 3.2$ & + & + & & + & + (micro) & $\mathrm{B}^{\prime}$ \\
\hline
\end{tabular}

- Diagnosed before operation

$\checkmark$ findout intra operative Sono

(micro), findout in resected specimen 


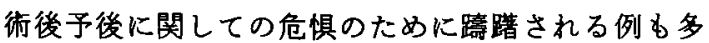
い. 又小肝癌の多くは被膜を持っていることが報告さ れており 2-4), 又肝硬変の中に発生した肝癌は発生当初 より被膜を持っているようなものであるので，そのよ らな被包化された肝癌では，周囲にわずかな非癌組織 を持たせた程度の奶除でも大きく根治性を落すことに はならないであろうとの考えより本術式を行ってきた あのである.

竜ら5) は小肝癌の組織学的娭討に基づき， $3 \mathrm{~cm}$ 以下 の例では surgical murgin を1cm とる切除です対処で きるとしており，私どすの $4 \mathrm{~cm}$ 以下の肝癌例で，超音 波㭘查にて被膜外浸潤なしとされた例では，標本上被 膜外漫潤があってもそれは $5 \mathrm{~mm}$ 以内にとどまってい るのでありやはり $1 \mathrm{~cm} の$ 非癌部を周囲に含めれば充 分に局所的には根治性のある切除となりらると考えら れる.

9 例の再発例があるが，その内いわゆる切除断端再 発と思われるるのは 3 例のみであり，大部分の例は核 出術でも外科的に局所切除し得ていたと考えられる.

断端再発例については, 術前, 術中の判断の誤りる 大きな原因となっていると考えられるが，これらは今 日の改良された超音波検查でなら防ぎ得るものであ る.

残る 6 例の再発は初回手術とは異なる区域への再発 でありこれらはむしろ多中心性発癌とる考劣られる 形である。しかしながら中島()，は肝癌部の血流動態打 よび門脈腫場栓などの検討より，多中心性発癌よりむ しろ肝内転移の可能性の方が高いとの考えのようであ るが，未だ決定手段のない現状である7゙.

肝硬変の中の小肝癌は比較的予後が良いので，はた して手術の効果があげられているのであろうかという 基本的な問題が指摘されているが，これは小肝癌の自 然歴，あるいは非観血的治療との予後の比較がなされ なければならないわけである。確かに肝癌に対する肝 動脈栓塞療法の成績は山田 らすの努力により向上が見 られており，小肝癌についてはより良い成績があげら れるものと思われる。

又手術予後す良好で，私どもの最近の手術成績の向 上の大きな要因として，肝癌全体の中で小肝癌の比率 が增してきていることがあげられる゙．

私どすの核出術の最長生存例は 4 年 6 力月であり, 3 年以上生存例。 7 例に見られ, 又累積生存率は 4 年 で52\%が得られていることを考えると，自然歴より恐 らく良いであろうし, 又肝動脈栓塞術でしばしば非癌
部肝組織への障害のため肝硬変を進行させた結果と なったと思われる症例などす考え合せると，現時点で は切除出来るものは摘出した方が良いのではなかろら かと思われる。

核出術で行らか否かの判断は最終的には術中超音波 検查で行っているが，私どもの局所再発例はこの術中 判断の誤りという要素が強かったとの反省がある。こ れは以前の術中超音波検查用のブローブの形態，機能 に不備な点があったため良好な像が得られなかったこ とは否めず,最近の新しいブロープの開発吕により,ど の位置からです良い像が得られるようになり，超音波 検查による病巣の病態診断が正確となった，私どもの 超音波による小さな訮癌における，被膜，被膜外浸潤， 娘結節の診断率は良好であり，実際には被膜がないも のに対し被膜ありと譔診したるのは33.3\%である. 又 被膜外漫潤があるものを無しと判定したものは $37.5 \%$ であるが,この上らな被膜外浸潤は被膜周囲 $5 \mathrm{~mm}$ にと どまるもののみである ${ }^{11}$. 結論的には術中超音波検查 にて，全周性の被膜を認め，しかも被膜外漫潤なし上 判断された例を適応として行えば，例え実際に被膜外 浸潤があっても，被膜周囲 $1 \mathrm{~cm}$ の範囲が切除されてい 九ば一応局所的には切除し得るといらこととなる。

核出術の根治性を向上させるための一つの補助手段 として術前肝動脈栓塞術併用に期待 ${ }^{12)}$ が持たれ，主腫 瘍は核出術を行い，娘結節，被膜外浸潤については TAEによる壊死效果を図る処置と考えて行ってみた が，本法により主腫場に対しては良好な効果を得られ るが, 娘結節, 被膜外浸潤, 又内脈腫場栓に対しては 大きな効果は望むことができないといら結果であり， 諸家 ${ }^{13.14)}$ の報告でるほとんど同じ成樍である。しかし 竜ら ${ }^{13)}$ は術後の再発率に関してはTAE 不施行例との 間に差を認めており，術中の播種性転移の抑制に効果 が期待できるとしている．更にわれわれはTAE 併用 例で壊死とならない娘結節などが門脈血により栄着さ れている点を重視し，経門脈的な化学療法を加えるへ く，核出術に引き続き，われわれの脾腹壁固定術 ${ }^{16)}$ 行っておき，㭪後の経脾的門脈内抗癌剤投与を検討し ている.

\section{結語}

（1）腫瘤核出術の予後調查で， 3 年以上生存は現在 生存中のむのむ含め 7 例であり, 累積生存率では 4 年 で52\%との結果が得られた．本術式の適応対象が肝硬 変症例であることを考光合わせると一応成り立つ術式 であると考兄られる。 
（2）切除断端再発とされる例は26例中 3 例である が,これらの症例の切除標本の病理組織学的検討によ ると, 被膜形成が不完全な例および被膜外浸潤が認め られている症例であった。これらの所見は術前より画 像診断にて予想されていたすのである.

（3）術前あるいは術中超音波検查で被膜があり，し かも被膜外漫潤はなしと診断された例では，たとえ切 除標本上で被膜外浸潤があってもそれは被膜の外周5 $\mathrm{mm}$ の範囲内にとどまっていた。

（4）本術式の適応決定に際しては術中超音波検查が 必須であり，根治性を得るためには，長径 $3 \mathrm{~cm}$ 以下， 被膜が全周性に認められ，しかも被膜外浸潤なしとさ れた症例に限ることが必要である.

文献

1) 高崎 健, 小林誠一郎, 武藤睛臣, 他: 高度肝硬変 合併小肝癌に対する腫瘤核出術. 日臨外会誌 $44: 462-465,1983$

2）山绮 晋, 長谷川博, 幕内雅敏：細小肝癌の臨床病 理学的分析と，それにもとつく新しい概念の切除 法一27切除例の検討一。肝蔵 $22: 1714-1724$, 1981

3）赤木 郷：細小肝癌. 内科 $52: 441-444,1983$

4) 神代正道：細小肝癌の病理。肝葴 $24: 1458,1983$

5) 竜 崇正：細小肝癌の診断と予後. 肝䐵 24 : $1464-1466,1983$

6) 中島郎：原発性肝癌をめぐる諸問題. 癌と化学 療法 6(臨時増刊 III)：403-412, 1979
7) 奥平雅彦，佐々木憲一：原発性肝癌は多中心性発 生か，肝胆嘩 5:933-937，1982

8）山田龍作, 佐藤年男：塞栓療法. 肝癌の治療之対策 一. medicina $20: 1538-1539,1983$

9）高崎 健, 武藤晴臣, 原田瑞也：切除し得た原発性 肝癌60例の予後の検討. 肝䁍 $23: 159-164,1982$

10）秋本 伸, 済陽高穂, 由里樹生, 他：穿刺溝付術中 超音波検查用探触子の開発. 画像診断 1 : $289-292,1981$

11）斉藤明子：投稿中

12) 厚生省がん研究助成金. 計画研究, 第15班(班長 長 谷川博)：肝癌に対する集学的治療. - Embolizationを併用した肝切除の検討一。肝胆满 5 ： 1195-1200, 1982

13）佐々木洋, 今岡真義, 松井征雄, 他：肝細胞癌にお ける術前 Transcatheter arterial embolization therapyの意羲について，日癌治 17 ： 1917-1924, 1982

14）田中信孝, 岡本英三, 豊坂昭弘, 他：肝細胞癌に対 する肝動脈遮断術の抗腫瘍効果に関する病理組織 学的検討. 日外会誌 $84: 518-528,1983$

15）竜 崇正，山本義一，山本 宏：細小肝癌に対する Transcatheter Arterial Embolization 併用肝切 除の意義. 肝臓 $25: 881-889,1984$

16）小林誠一郎, 高崎 健, 原田瑞也, 他：脾腹壁固着 術一程門脈的抗癌剤投与一. 外科治療 40 ： 267-270, 1979 . 


\title{
Results of tumor enucleation for small liver cancer
}

\author{
Ken Takasaki, Seiichiro Kobayashi, Haruomi Muto, Takaho Watayo, \\ Akiko SAITo, Shin AKımoto, Yoshinori ISOBE, \\ Tetsuya AGETA and Hiroshi OBATA*
}

Operative results of tumor enucleation method as minimized surgical treatment for small liver cancer patient with liver cirrhosis is reviewed.

Over 3 years survivor counts 7 cases, and 5 is still alive, with a 4 years 6 months of longest survivor, and cummurated 4 years survival rate is $52 \%$.

Postoperative recurrence is seen in 9 patients. In 6 cases of this group, recuned tumor appeared in another segment from the site which had contained the primary tumor, while in 3 cases of it, recurrence was seen in the area clore to the cutting sunface.

His to pathological examination of there 3 marginally recuned cases revealed the nature of tumor as in complate capsel formation or extra capurale invasion which suggests as the retaining cancer cells in surrounding unresected tissue.

This fact strongly proclaims us that operative indication should he more serious to improve the radicality of whole tumor.

We consider that the method of tumor enucleation should her performed only in tiny lesion less than $3 \mathrm{~cm}$ in cliameter and has obvious capsel without extra capsurale invasion or any intra hepatic metastasis.

For accomplischment to this purpose, real time US monitoring especially intra operative ultra sonography is very useful.

\footnotetext{
* Institute of Gastroenterology, Tokyo Women's Medical College (Tokyo)
} 